volume of air free from all currents and a cubic centimetre of water free from all impurities, are both of them well-nigh equally difficult of realisation. The exact determination of such constants is nevertheless of the greatest scientific interest, and even the difference between their values and those obtained under more normal conditions affords a measure of the allowance that must be made for the discrepancies which exist between theory and practice.

Canovetti's experiments, on the other hand, are essentially of the rough and ready order in several respects. The wire hanging as it does in a catenary, the differences of inclination at different parts of the course render the motion far from uniform over the 280 metres, and the estimated velocities can only be regarded as average velocities in a motion with variable velocity, the details of which have not been fully investigated. A further source of error is due to the sagging of the wire at the point where the trolley rests on it, and the consequent absorption of energy in producing vibrations. It is thus not surprising to find that Canovetti obtains 90 grammes for the resistance of a rectangle where Le Dantec finds $8 \mathrm{I}$ grammes; one might not unreasonably have expected a greater discrepancy. Although Canovetti avoided windy days, yet his experiments were conducted in the open air under conditions which might be regarded as normal in ordinary calm weather, and so far as the results bear on the question of the relative efficacies of different forms of balloons and other bodies in overcoming air resistance, they may be regarded as furnishing data of considerable practical value.

G. H. BRYAN.

\section{DR. HENRY HICKS, F.R.S.}

$\mathrm{B}^{\mathrm{RITISH}}$ geology suffers a severe loss in the death of Dr. Henry Hicks, a loss which will long be felt on personal as well as scientific grounds. His chief work was in South Wales, among the older Palæozoic formations, whose life-history was previously but little known. He pushed his inquiries into the very oldest pre-Cambrian rocks, both in Wales and Scotland; and then turning from these most ancient records he gave attention to those immediately preceding the present order of things, and pursued with equal ardour the evidences of glaciation in South Wales and Middlesex, the records of old bone-caves, and the remains of mammoth in the Thames Valley. No man had a keener eye for fossils. To him rocks which had for long been deemed unfossiliferous yielded up some evidences of life.

Now and again his enthusiasm led him to draw conclusions and express opinions that were too slenderly supported by evidence, and consequently he was brought perhaps more than any other man of his time into active conflict on the battle-field of geology. No one, however, seemed to enjoy more heartily the animated debates which his own papers so often provoked than Dr. Hicks.

Henry Hicks was born at St. David's, in Pembrokeshire, in 1837 , and was educated at the Collegiate and Chapter School in that city. Coming to London to study for the medical profession, he entered Guy's Hospital, and was admitted a Member of the Royal College of Surgeons and a Licentrate of the Society of Apothecaries in I862. Returning then to his native place he commenced a practice which he continued until $187 \mathrm{I}$, when he removed to Hendon. He now devoted special attention to mental diseases, took the M.D. degree at St. Andrews in 1878 , and continued his active and useful medical work until the close of his life.

It was in 1863 , while resident at St. David's, that Dr. Hicks' attention was first attracted to geology, and the inspiration came through the late J. W. Salter, then palæontologist to the Geological Survey. In the previous year Salter had himself discovered, for the first time in
Britain, remains of the large Trilobite Paradoxides, which was then stated to occur in the "Lower Lingula Flags," of St. David's. Dr. Hicks' interest was aroused ; he diligently commenced to search for fossils among the old rocks around him, and as he himself has told, the enthusiasm with which every new find was welcomed by Salter, "to whom they were first sent, was in itself a sufficient stimulus for any exertions required." A grant in aid was received from the British Association in 1863 , and in the following year Salter was enabled to report at the Bath meeting that the energetic work of Dr. Hicks "has already brought to light more than thirty species of fossils, most of them Trilobites"; and as he elsewhere remarked, these discoveries "made a large addition to the Primordial fauna."

With the help and encouragement thus given by Salter Dr. Hicks pursued his work with unflagging devotion. His first communication to the Geological Society was made in 1865, and dealt with the genus Anopolenus; and from that date onwards for some years he contributed a series of most important papers on the stratigraphy and palæontology of the Cambrian and Lower Silurian rocks of South Wales, two or three of the earlier papers in conjunction with Salter or Robert Harkness. These researches led to the establishment of the Menevian group in 1865 by Salter and Hicks for part of the Middle Cambrian division which is characterised by Paradoxides Davidis \&c.

In 1876 he communicated a more particular account of the pre-Cambrian rocks of Pembrokeshire, and here he came perhaps more into conflict than on any previous occasion. The granitoid rock which he named Dimetian and claimed as pre-Cambrian was regarded by Sir A. Ramsay as metamorphosed Cambrian, and afterwards by $\operatorname{Sir}$ A. Geikie as a granite mass intruded into the Cambrian rocks. The Pebidian volcanic series, also regarded as pre-Cambrian by Dr. Hicks, was grouped with the Cambrian by Sir A. Geikie. The evidence for a third and intermediate series named Arvonian by Dr. Hicks was subsequently admitted by him to be inconclusive. In his views concerning the antiquity of the Dimetian, Dr. Hicks was strongly supported by Prof. Bonney, Prof. Hughes and Mr. Thomas Davies. With regard to the Pebidian, it is now recognised that the beds are of the type of the Uriconian of Shropshire, generally classed as pre-Cambrian.

Between 1878 and I883, Dr. Hicks published a series of papers on the metamorphic and overlying rocks of parts of Ross-shire and Inverness-shire, with petrological notes by Prof. Bonney and Mr. T. Davies.

Since he went to reside at Hendon, Dr. Hicks gave much attention to the local geology, and recorded many facts of interest. In course of time the subject of bonecaves greatly occupied him, and Cae Gwyn Cave in particular was explored in company with Mr. E. B. Luxmoore and others. It was then shown that this Denbighshire cavern was occupied by an early Pleistocene fauna and by man before the deposition of any of the local glacial deposits.

In 1890 Dr. Hicks bent his steps into North Devon, and was much struck with the evidences of folding, faulting and crushing near Ilfracombe. He then for the first time found a Lingula in the Morte Slates, and expressed the opinion that these rocks were older than the Devonian. Working zealously in Devonshire, and revisiting South Pembrokeshire for the sake of comparisons, he elaborated his views in 1896 and 1897 . He had now succeeded in finding a number of fossils in the Morte Slates and in different localities, but whether these were in part true Silurian fossils as maintained by Dr. Hicks and the Rev. G. F. Whidborne, or wholly Lower Devonian, Dr. Hicks had clearly shown that the suc. cession across North Devon was not continuous and unbroken as had been supposed. The discovery of the

NO. I 570 , vOL. 6I] 
fossils was indeed a grand one, and it indicated also that the Morte Slates "vary considerably in different areas, and probably include beds of very different age."

These, his last researches, were carried out with all the enthusiasm of his earlier work, and when first announced to the Geological Society they roused as much opposition. The fact is that when he read the first paper only one Lingula had been found in the Morte Slates, and it was felt that the conclusions drawn by the author were not justified. Undaunted, he returned again and again to the field; he reaped a rich harvest where others had altogether failed, and if he did not succeed in demonstrating that Silurian rocks occur in North Devon, he at any rate made manifest that until better preserved fossils are obtained it is not safe to say they are not there.

Dr. Hicks became a Fellow of the Geological Society in $187 \mathrm{I}$; for many years he served on the Council, he was one of the honorary secretaries from 1890-93, and president from February 1896 to February 1898 . 'The Bigsby Medal was awarded to him by the Council in I883. Dr. Hicks had also been President of the Geologists' Association, 1883 to 1885 . He was elected a Fellow of the Royal Society in 1885 . In his busy professional life he found geology a "means of recreation and of much intellectual enjoyment"; and until near the close of his life he maintained a youthful energy and vivacity, and looked the picture of health. To his many friends the sad tidings of his death at Hendon on November 18 , at the age of sixty-two, came as a surprise, and everywhere raised feelings of the utmost sorrow.

\section{H. B. W.}

\section{NOTES.}

THE sum of fifteen thousand marks appears in the Budget of the German Imperial Home Office as Germany's contribution towards the preparation of an international catalogue of science.

THE Electrician states that a school for wireless telegraphy is being established on one of the Government hulks in Portsmouth harbour.

M. DE Copper has forwarded to the treasurer of the French Physical Society a cheque for 1000 francs towards meeting the expenses of printing the "Receuil des Constantes Physiques."

AT the annual meeting of the Royal Institution of Cornwall held at Truro on November 21, under the presidency of the Rev. S. Baring-Gould, the Henwood Gold Medal was presented to Mr. Rupert Vallentin for his observations on the fauna of Falmouth, accounts of which are published in the last three numbers of the fournal of the Institution.

The Walsingham Gold Medal of the University of Cam. bridge has been awarded to Mr. H. H. W. Pearson, Assistant for India in the Kew Herbarium. This medal is obtained by competition in original essays on any branch of biological science. Mr. Pearson's essay was on the botany of the Ceylon Patamas, recently published in the Journal of the Linnean Society.

Prof. Karl Pearson, F.R.S., will deliver a lecture entitled "Matter and Motion" in the chemical theatre of University College, Gower-street, on December 6 at 5 P.M. The members of the Chemical and Physical Society invite the presence of all who are interested in the subject.

THE fourth international congress of psychology will be held at Paris, in connection with the international exhibition, on August 20-25, 1900. It is hoped that all who are interested in the study of psychology in its various aspects will take part in the congress. The general secretary is Dr. Pierre Janet, Rue NU. I 570 , VOL. BI]
Barbet-de-Jouy 21, Paris, to which address all communications concerning membership should be sent.

WE regret to learn, from the Botanisches Centralblatt, of the death of Prof. P. Knuth, at Kiel, on October 30 , in the fortyfifth year of his age, shortly after his return from a long journey. Dr. Knuth had worked on the same lines as the late Dr. Hermann Müller, in collecting an immense amount of information respecting the visits of insects to flowers and their agency in cross-fertilisation. Only last year he published the first and second volumesiof his " Handbuch der Blitenbiologie," in which every observation of importance made by himself or others recorded during the last quarter of a century, since the publication of Müller's "Befruchtung der Blumen," is collated. A third volume remained unpublished at the time of his death.

IT appears from a detailed article in Engineering that the British display at the Paris International Exhibition next year will be quite unworthy of the manufacturing power of this country. This, we need hardly remark, is a matter for deep regret, especially as our chief competitors are arranging fo: exhibits on a very large scale. The German display will be of the first magnitude. Thus the German exhibit in the group of appliances and general processes relating to literature, science and art, will be contained in a separate pavilion, the contents of which will be valued between three and four million marks. In the group devoted to decoration of buildings, furniture, \&c., the value of exhibits is estimated at $150,000 l$, and a similar value is set on Germany's electrical exhibits. The value of exhibited general machinery is stated to be $35,000 l$; agricultural exhibits 20,000l.; the naval and military exhibit $30,000 l$, and so on. The total value of German exhibits is estimated at a million sterling. British industries and science will only be represented by 642 exhibitors. Referring to the inferiority of the representation of Great Britain at the Exhibition in comparison with other countries, Engineering remarks: "Manufacturers best know what are their own interests, and they have presumably come forward in such small numbers only after careful consideration. Possibly this apparent indifference is partly due to the remarkable absence of information available about the Exhibition, and partly because of the unsatisfactory arrangement, from an exhibitor's point of view, by which exhibits will be scattered over a large area, instead of being concentrated into a British section. But whatever the causes, we must be prepared to meet our chief competitors in as many thousands as we number hundreds; if manufacturers are then disappointed, they will only have themselves to blame. One reason of our inferiority in numbers is, no doubt, to be found in the antipathy of the British industrial to co-operate in industrial exhibits. $\mathrm{He}$ stands alone in this prejudice, and has, of course, to pay the penalty."

THE claims of inorganic chemistry to increased attention have recently been urged in Germany on two important occasions. Addressing the Naturforscher-versammlung at Diisseldorf last year, Prof. van 't Hoff gave a most interesting review of the recent achievements of inorganic chemistry, and made a strong plea for the cultivation of this branch of the science. This plea has been put in a more concrete form at the Göttingen meeting of the German Electrochemical Society. The subject was introduced on this occasion by Prof. W. Hittorf, and the proceedings culminated in a letter addressed to the Minister of Education asking definitely for the establishment of professorships and laboratories for inorganic chemistry.

Prof. HitTorf points out how largely German chemists have deserted inorganic for organic chemistry; how, with the exception of the late Victor Meyer, hardly an organic chemist of the later school has made important contributions to inorganic 